\section{LA DIMENSIÓN LÚDICA DE LA OBRA ARQUITECTÓNICA DE LINA BO BARDI}

\author{
THE PLAYFUL SIDE OF LINA BO BARDI'S ARCHITECTURAL \\ WORK
}

\author{
María Isabel Alba Dorado
}

Boletín Académico.

Revista de investigación y arquitectura contemporánea.

Escola Técnica Superior de Arquitectura.

Universidade da Coruña.

ISSN 0213-3474

eISSN 2173-6723

http://revistas.udc.es/index.php/BAC

Número 9 (2019) | Páginas 109-128

DOI: https://doi.org/10.17979/

bac.2019.9.0.4647

Fecha de recepción $\quad 31.10 .2018$

Fecha de aceptación $\quad 23.04 .2019$

Este trabajo está autorizado por una

Licencia de Atribución de Bienes

Comunes Creativos (CC) 3.0

\section{Palabras clave}

Lina Bo Bardi, lúdico, juego, espacio público, colectividad

of architect Lina Bo Bardi to explore the more humane, free, unprejudiced and playful side of her architectural work. This will lead us to unveil a much more complex past than one might initially think, where the architect applies a particular human sensitivity that is perceptible in all of her work and where people stand at the centre of her priorities. Behind her wild fantasy and imagination lies the complexity and depth of focused, conscientious, coherent, self-critical and socially committed work. This has produced an open, porous architecture that ties in the joy and unpredictable essence of everyday life, nourishing collective spaces and embracing people's way of life.

\section{Keywords}

Lina Bo Bardi, playful, play, public space, collectivity 


\section{Introducción}

"Si volviera a nacer, solo coleccionaría amores, fantasías, emociones y alegrías". ${ }^{1}$

Lina Bo Bardi

Cuando Lina Bo Bardi, nacida en Roma y formada como arquitecta en la capital italiana, llegó a Brasil acompañada de Pietro María Bardi, esta traía consigo los grandes ideales, el compromiso moral, político, cultural y ético que marcó la época de reconstrucción en Italia y el deseo de humanizar la arquitectura prestando especial atención a las necesidades cotidianas de la gente. En este país halló el lugar donde poder construir desde una libertad creativa un mundo nuevo para un pueblo nuevo ${ }^{2}$, combinando su fuerte formación histórica recibida en Italia con la indagación de nuevas fronteras desde las que desarrollar su actividad creativa.

"Hija legítima de las vanguardias europeas"3, Lina ${ }^{4}$ pertenece a la tercera generación de arquitectos del siglo XX caracterizados por la voluntad de dar continuidad a las propuestas de los maestros del Movimiento Moderno, pero, al mismo tiempo, de impulsar una necesaria renovación y transformación del discurso de la modernidad. Más que al lenguaje formal y abstracto de la arquitectura moderna, Lina fue fiel al concepto liberador de modernidad. En este sentido, Lina, más que una arquitecta moderna inflexible, entregada a la modernidad sin restricciones, fue una diseñadora y teórica que trató de encontrar el equilibrio entre el rigor y la libertad, atenta a los detalles de la vida cotidiana, a la simplificación técnica y a los valores de lo vernáculo.

Desde su llegada a Brasil, Lina participó de una forma muy activa en el debate cultural y arquitectónico de este país. Su amplia actividad le llevó a ejercer la profesión en otras áreas además de la arquitectónica, abriéndose camino en el arte popular, la escenografía, la ilustración, el ámbito académico, el diseño de muebles y objetos, entre otros.

Su viaje al Nordeste de Brasil la marcó profundamente. Allí entró en contacto

\section{Introduction}

"If I were born again, I would only collect loves, fantasies, emotions and joys".

Lina Bo Bardi

Born in Rome and qualified in architecture in the Italian capital, Lina Bo Bardi came to Brazil along with Pietro María Bardi, bringing with her a suitcase full of bright ideas, morals, political, cultural and ethical convictions marked by the age of reconstruction in Italy and the will to humanise architecture with a special focus on people's everyday needs. In Brazil, Lina found a place to build with creative freedom in a new world for a new people ${ }^{2}$, combining her sound historical education from Italy with the thirst to explore new boundaries for her creative activity.

Described as the "legitimate daughter of the European avant-garde"3, Lina ${ }^{4}$ belongs to the third generation of 20th century architects, who were known for their goal following up the proposals of the masters of the Modern Movement, while at the same time pushing for a renewal and transformation in the discourse of modernity. Rather than the formal and abstract language of modern architecture, Lina was true to the liberating concept of modernity. ${ }^{5}$ Indeed, rather than an adamant modern architect with an unrestricted dedication to modernity, Lina was a designer and theorist who endeavoured to strike a balance between rigour and freedom, with a watchful eye on the peculiarities of everyday life and the value of all things vernacular.

Ever since her arrival in Brazil, Bo Bardi took on an active role in the country's cultural and architectural debates. Her broad-ranging activity led her to work in other fields as well as architecture, which included venturing into folk art, scenography, illustration, academia, and designing furniture and objects.

Her journey to the Northeast of Brazil made a deep impression. It was there 
con una arquitectura primitiva y popular, conoció los hábitos de sus gentes, su intuición material y su capacidad resolutiva. ${ }^{6}$ Esto le llevó a establecer vínculos con una cultura popular diferente, más desinhibida que la que había conocido hasta ese momento, lo que le llevó a iniciar un proceso de transformación que encontró su reflejo en su quehacer arquitectónico, en sus obras creativas, pero también en su persona y en el modo de concebir la vida. Lina recorrió el país adentrándose en un mundo todavía desconocido para ella, dejándose fascinar por él y explorándolo con la misma despreocupación de un niño. Brasil se extendía ante sus ojos como un campo de juegos infinito en el que dar forma libremente a su pensamiento creativo. ${ }^{7}$

Su curiosidad antropológica le llevó a realizar un exhaustivo inventario de objetos del nordeste entre los que se encontraban multitud de juguetes realizados a partir del reciclaje de materiales extraños y que ella coleccionó de forma obsesiva. Estos objetos junto a las tradiciones, cultos y fiestas populares vividas por ella en el nordeste impregnaron su imaginario creativo, haciendo que su discurso arquitectónico, formado en las vanguardias, se volviese antropológico.

Interesada en la cultura regional brasileña y las tradiciones populares, se convirtió en una defensora de los espacios y los valores públicos. Su respeto por el ser humano y su preocupación por satisfacer sus necesidades a través de una arquitectura conectada a la vida guió su trabajo. Situó a las personas, su entorno cultural, medioambiental y social, y sus necesidades materiales y espirituales en el punto de origen, pero también en el fin de toda su actividad. A través de su obra y a partir de su peculiar sensibilidad humana, Lina se esforzó por experimentar y materializar programas que enriquecieran la vida colectiva a partir de la creación de ambientes abiertos capaces de adaptarse a lo imprevisto, de acoger la contingencia y la espontaneidad de la vida cotidiana y de dar respuesta a las necesidades de los usuarios más que por tratar de controlar todas las variables de su diseño o buscar that she came into contact with a primitive folk architecture, learned the customs of the local people, their material intuition and their resourceful abilities. ${ }^{6}$ This led her to build bonds with a different type of folk culture, a more uninhibited culture than she had thus far been familiar with, guiding her to embark on a process of transformation that would find its echo in her architectural practice and creative work, but also in herself and her way of seeing life. Bo Bardi explored the country venturing into a world that was unknown to her, allowing herself to become fascinated by it and to discover it with the woeless awe of a child. Brazil was unfolding before her very eyes into a boundless playing field in which to give her creative thought free reign. ${ }^{7}$

Her anthropological curiosity led her to draw up an unabridged inventory of objects from the Northeast, including a list of toys made out of unusual recycled materials that she collected obsessively. These items, along with the popular traditions, tributes and festivities she experienced there, seeped deep into her creative imaginary, putting an anthropological taint on her originally avant-garde architectural discourse.

Fascinated as she was by Brazil's regional culture and folklore, she became a defender of public spaces and values. Her respect for humankind and her concern of catering for its needs through architecture linked to life was what guided her work. Lina placed people, their cultural, environmental and social surroundings and their material and spiritual needs at the beginning and end of everything she did. Through her work and her unusual human sensitivity, Lina sought to experiment with and bring to fruition programmes that would enrich collective life by creating open environments with the ability to adapt to the unexpected, to take the contingencies and spontaneity of everyday life in their stride, and to cater to the needs of users beyond seeking to control the variables of their design or to create an aesthetically pleasing 
una imagen estética agradable. Esto le llevó en el desarrollo de sus obras a concentrarse no solo en sus aspectos más funcionales, sino también en aquellos más lúdicos los cuales tenían para la arquitecta un sentido eminentemente constructivo.

En su obra nos es posible evidenciar un concepto de lo lúdico relacionado con la necesidad de dar soporte y satisfacer los deseos de las personas y en el que el aspecto más competitivo, vinculado a manifestaciones de tensión entre individuos, es abolido, primando una concepción mucho más colectiva. En su empeńo de conectar juego y vida, Lina se situó próxima al concepto de homo ludens enunciado por el filósofo e historiador Johan Huitzinga ${ }^{8}$ en 1938. En el desarrollo de su proceso creativo, el juego colectivo fue ganando cada vez más protagonismo. A través de su arquitectura colectiva, Lina trató de desdibujar los límites entre el juego y la vida cotidiana, lo que se manifestó no solo en ese espíritu libre y festivo presente en los proyectos que construyó, sino también en la alegría que desprendían muchas de las exposiciones y objetos que diseñó, los cuales participaban de las características del juego.

El presente artículo tiene como objetivo desvelar esta dimensión más humana, libre, desprejuiciada y lúdica presente en la obra de Lina Bo Bardi a partir del estudio y análisis de su trayectoria profesional, así como de algunas de sus principales obras públicas, exposiciones, objetos y juguetes que la arquitecta diseñó y creó para estos espacios. Este estudio nos llevará a hacer habitable en el desarrollo de estas páginas ese mundo lúdico que formaba parte de la compleja y enigmática personalidad de una creadora absolutamente inusual como era Lina Bo Bardi.

Asimismo, este artículo vendrá a añadir a la literatura sobre la arquitecta una componente menos conocida y a la que en pocas ocasiones se hace referencia, pero que resulta esencial para comprender su universo creativo y su trayectoria profesional como es su dimensión más lúdica, alegre, festiva $\mathrm{y}$, al mismo tiempo, humanista, ética y crítica. image. This drove the development of Bo Bardi's work to focus not only on the more functional aspects, but also on the more playful factors that gave architecture an eminently constructive meaning.

Her work reveals a playful concept linked to the need to support and satisfy people's desires, which abolishes the competitive side associated with tension among individuals and draws on a much more collective purpose. In her resolve to connect life and play, Lina came close to the homo ludens concept enunciated by the philosopher and historian Johan Huizinga ${ }^{8}$ in 1938. As her creative process developed, collective play gradually gained significance. Through her collective architecture, Lina sought to fade the boundaries between play and everyday life, which became apparent not only in the festive free spirit shown in the projects she built, but also in the joy emanating from so many of the exhibitions and objects she designed, with their game-like features.

The purpose of this paper is to unveil the more humane, free, unprejudiced and playful side of Lina Bo Bardi's work by studying and analysing her professional journey together with some of the main public works, exhibitions, objects and toys designed and created by this architect for the spaces she built. Reading the pages of this study will lead us to see the inhabitability of this playful world housed inside the complex and enigmatic personality of such an absolutely out-of-the-ordinary creator as Lina Bo Bardi.

This paper will build on the literature about this architect with a less-known element that is rarely mentioned but which proves instrumental in understanding her creative universe and professional journey - namely, her more playful, cheerful, festive and also humane, ethical and critical dimension. 


\section{Método}

Para alcanzar los objetivos planteados, en un primer momento nos iniciaremos en el estudio del proceso creativo de Lina Bo Bardi deteniéndonos en aquellos aspectos a través de los cuales la arquitecta trató de humanizar su arquitectura, convirtiéndose en la "más valiente hacedora de caminos de la modernidad" necesidades cotidianas del hombre a partir de la materialización de programas que alimentasen la vida colectiva y la definición de espacios públicos que abrazasen la forma de vivir de la gente e incorporasen la imprevisibilidad de la vida desde una actitud libre, alegre, festiva y desprejuiciada.

Posteriormente, este estudio se detendrá en el análisis de algunas de sus principales obras arquitectónicas como son: el Museo de Arte de São Paulo (MASP) (1958-1968), el SESC Pompéia (19771986) y el Teatro Oficina (1980-1991). La selección de estas arquitecturas ha estado motivada por la capacidad de estas para acoger la vitalidad y la participación de las personas y, al mismo tiempo, por ser capaces de provocar esto mismo: crear un lugar para la fiesta, la sorpresa, la fantasía y el ocio, donde el miedo y la inhibición desaparecen para que el usuario se deje arrastrar por el placer del juego.

Asimismo, esta selección ha estado determinada por la relación de estas arquitecturas públicas con aquellos eventos, exposiciones u objetos que Lina creó desde el juego y que lograron mejorar la cualidad colectiva de estos espacios, enriqueciendo y alegrando la vida de las personas. Es el caso de las exposiciones bobardianas del SESC Pompéia, los objetos escenográficos del Teatro Oficina, Dodecaedro y Polochón, o los juguetes colectivos como la Gran Vaca Mecánica o el Pequeño Tren de Carritos elaborados por Lina para el MASP y el SESC, respectivamente.

Para abordar este estudio, nos sumergiremos en la trayectoria arquitectónica de Lina como lo haría un niño, tratando de desvelar ese

\section{Method}

In order to fulfil its intended purpose, this paper will start by studying the creative process of Lina Bo Bardi, lingering on some of the aspects that the architect used in an effort to humanise architecture and that made her "the bravest paver of pathways of modernity". " Lina addressed the everyday needs of mankind by materialising programmes that would nourish collective life and defined public spaces that would embrace people's way of life and cater for life's unforeseeable nature with a free, joyous, festive and unprejudiced attitude.

The study will then go on to analyse some of her main architectural work, including the Museum of Art of São Paulo (MASP) (1958-1968), the SESC Pompéia (1977-1986) and the Teatro Oficina (1980-1991). The reason for choosing these architectural achievements lies in their ability to foster and inspire people's vitality and involvement, in the power to create a place for celebration, surprises, fantasy and leisure, where fear and inhibition make way for users to be taken over by the pleasure of play.

The choice has also been based on the correlation between these public works and the events, exhibitions and objects that Bo Bardi created in them from a playful perspective, which managed to enhance the collective worth of these venues by making people's lives richer and happier. Such is the case of the Bobardian exhibitions inside the SESC Pompéia complex, the props at the Teatro Oficina, Dodecaedro and Polochón, and collective toys such as the Great Mechanical Cow or the Little Train of Carts created by Lina, the former for the MASP and the latter for the SESC.

The study will be undertaken by venturing deep into Bo Bardi's architectural journey just as a child would and endeavouring to reveal that 
espíritu alegre y festivo presente en su obra. Esto nos llevará a explorar la influencia del concepto de juego en su producción arquitectónica, ahondando en aquellas relaciones más inadvertidas e inusitadas que su obra guarda con las características propias de lo lúdico y del juego, distanciándonos de una lectura más clásica de su obra.

En este sentido, se optará por el análisis de las arquitecturas seleccionadas a través de un enfoque poliédrico que nos lleve a adentrarnos en el mundo del juego y del juguete en la obra de Lina, aportando una visión más amplia e integradora de esta capaz de desvelar el diálogo y las relaciones de pertenencia que se establecen entre las exposiciones, objetos y juguetes diseñados por Lina y su arquitectura colectiva.

\section{Resultados}

En Lina nos encontramos con creaciones de una excepcional originalidad, imaginativas, intransigentes y comprometidas con la sociedad. En el desarrollo de su obra se dejó poseer por la espontaneidad y la autenticidad de quienes carecían de medios materiales, pero poseían una gran capacidad creativa. Profundizó en los objetos creados por los propios niños, en ellos encontró las claves de su pensamiento.

Creó desde la libertad de un niño, derrochando fantasía y vitalidad. En Brasil encontró su terreno de juego, la posibilidad de desarrollar su arquitectura desde una libertad creativa. $\mathrm{Y}$, aunque siempre quiso ser adulta ${ }^{10}$, cuando alcanzó la madurez sintió la necesidad de rescatar su infancia ${ }^{11}$ para desaprender lo aprendido, para volver a mirar el mundo con los ojos de un niño.

En sus proyectos nos es posible observar la presencia tanto de la arquitecta adulta como la de la niña que fue, aunque esta última comenzó a prevalecer de forma gradual, pero sin llegar a anular a la otra. La mentalidad adulta que Lina traía consigo en su llegada a Brasil, fruto de su formación técnica y cultural en Italia, unida a la lógica racional o el conocimiento científico, poco a poco joyous, festive spirit underlying her work. This will lead us to explore the influence of the concept of play on her architectural production, delving into the more unnoticed and unusual links between her work and the typical characteristics of games and playfulness, guiding us away from a more classical reading of her work.

Along these lines, we have chosen to analyse the selected architecture from a multifaceted approach that will usher us into Lina Bo Bardi's universe of games and toys, affording a much broader and more encompassing view of her work and allowing us to uncover the dialogue and sense of belonging between her exhibitions, objects and toys and her collective architecture.

\section{Results}

Bo Bardi has provided us with creations of exceptional originality, imagination, intransigence and social commitment. When developing her work, she was gladly taken over by the spontaneity and authenticity of those who lacked material possessions but boasted great creative ability. Lina unpicked the items created even by children, which was where she found the key to their thoughts.

Her creations came from the freedom of a child, emanating fantasy and vitality. Lina found her playing field in Brazil and the chance to develop her architecture with a new creative freedom. Although she had always wanted to be an adult ${ }^{10}$, when Lina reached maturity, she felt the urge to retrieve her childhood ${ }^{11}$ and forget everything she had learned so as to see the world through the eyes of a child once more.

Her projects allow us to glimpse both the adult architect and the young girl she had once been. In fact, the latter gradually began to prevail, though never overriding the former. The adult mindset that Bo Bardi carried with her to Brazil, shaped by her technical training and her cultural background in Italy, along with her rational logic and scientific knowledge, slowly but 
comenzó a convivir de forma armoniosa con aquella mentalidad más lúdica e infantil que elogiaba la espontaneidad de la naturaleza y la cultura popular y que perduraría en su etapa de madurez como arquitecta.

Esta actitud lúdica nos es posible desvelarla no solo en las obras que concibió, sino también en su proceso creativo, en su persona y en el modo de entender la vida. Lina proyectaba con la misma actitud lúdica con la que un niño juega a construir ciudades e inventar mundos. Sus dibujos, provistos de una gran expresividad, se situaban muy próximos a la concreción final de cada proyecto. $\mathrm{Al}$ observar los bocetos y croquis que precedían a aquella documentación más técnica (maquetas, planos, etc.) con la que Lina presentaba sus proyectos, nos encontramos como estos, aparentemente infantiles, como expresó Marcelo Ferraz $^{12}$, escondían no solo una gran habilidad para la representación gráfica y el diseño de propuestas arquitectónicas de una gran rotundidad, sino que también mostraban una inagotable fantasía e imaginación, al tiempo que transmitían alegría y felicidad.

En su persona se hizo realidad la máxima de Johannes Itten, profesor de la Bauhaus: "El juego será fiesta, la fiesta será trabajo, el trabajo será juego". ${ }^{13}$ Lina comenzó a forjar su universo creativo desde niña, cuando comenzó a dibujar. Acuarelas de colores intensos que mostraban escenas festivas y reuniones populares italianas, en las que niños y adultos convivían en un ambiente relajado y feliz, fueron realizadas por Lina durante su adolescencia y estuvieron presentes en su etapa posterior como arquitecta. El recurso del dibujo infantil le sirvió en su edad adulta como fuente de inspiración. Sus dibujos de madurez, al igual que su arquitectura, evolucionaron hacia una forma de expresión desprovista de adornos, llena de energía y felicidad que se aleja de un lenguaje más académico para aproximarse a una forma de expresión más espontánea.

Su etapa brasileña le llevó a explorar con los ojos de un niño un mundo desconocido hasta entonces para ella y que fijó en su memoria. Se permitió el surely began to make room for the more playful and childish mentality that praised the spontaneity of nature and folk culture, allowing the two to live together in harmony throughout her architectural maturity.

This playful light shines through not only in the work she produced, but in her entire creative process, in her personality and in her way of understanding life. Lina would face her projects with the same playful attitude as a child pretending to build a city and worlds of make-believe. Her drawings, full of expressive power, were always close to the final execution of every project. Looking at the sketches and outlines that preceded the more technical documents (such as models and plans) that Lina used to present her projects, we notice that behind their seemingly childish appearance, as worded by Marcelo Ferraz, ${ }^{12}$ lay not only a masterful skill for graphically representing and designing powerful architectural proposals, but also boundless fantasy and imagination, joy and happiness.

Bo Bardi embodied the maxim of Johannes Itten, a master of Bauhaus: "Play becomes joy, joy becomes work, work becomes play". ${ }^{13}$ Lina began to shape her creative universe as a child, when she started to draw. Colourful water paintings brightly depicting festive scenes and Italian folk gatherings, where children and adults coexisted in a relaxed, joyous atmosphere, were painted by Lina during her adolescence and pervaded in her subsequent stage as an architect. Child-like drawings were a useful source of inspiration for Lina in her adult life. In maturity, her drawings, like her architecture, evolved towards an unadorned means of expressing herself, full of energy and happiness, far from a more conventional academic language to achieve greater spontaneity.

Lina's Brazilian phase led her to explore a world that she had never known before through the eyes of a child and this became engraved in her memory. She 
lujo de soñar con la poética, de crear con esos tiempos dilatados, como los que acompañan a la infancia, en los que la urgencia no existe, para dejarse perder en juegos colectivos interminables que poco a poco fueron ganando protagonismo en su quehacer creativo.

Su búsqueda de un nuevo humanismo festivo le llevó a interesarse también por todos aquellos juegos y actividades que ayudaran a enriquecer la vida de las personas ya fuese a través de eventos, exposiciones $\mathrm{u}$ objetos de carácter lúdico. Así pues, en su universo imaginario habitaron un sinfín de juguetes, carruseles, carritos, marionetas, locomotoras, pequeños bichos como insectos y otros más grandes como Polochón o la Gran Vaca Mecánica. $\mathrm{Al}$ analizarlos, observamos como en ellos existe una doble finalidad lúdica y pedagógica. ${ }^{14}$ Esta doble condición, aparentemente contradictoria, capaz de hilvanar lo intelectual con lo lúdico, la encontramos también en su arquitectura. Muchos de estos juguetes pertenecen a su arquitectura colectiva y son los causantes de desencadenar la actividad y mejorar la cualidad colectiva de los espacios que habitan. Como afirma Mara Sánchez, "juguetes y juegos son precursores de la compleja obra bobardiana”. ${ }^{15}$

Los espacios diseñados por Lina tenían como objetivo acoger la felicidad, lo que para la arquitecta suponía un encuentro con la libertad. Sus obras ofrecían el soporte para que tuviese lugar una gran fiesta para niños y adultos, un lugar en el que dejar atrás las inhibiciones, los miedos, los prejuicios y dejarse llevar por el misterio, la sorpresa y el placer del juego. Un juego libre y reglado al mismo tiempo, capaz de alcanzar una dimensión social y cultural relevante a través del diseño de sus espacios públicos y como resultado de una idea de colectividad muy importante en su obra.

Esta actitud abierta, flexible, capaz de acoger la imprevisibilidad y la alegría de la vida cotidiana presente en su obra encontraba además su correspondencia en su forma de proyectar. Lina no proyectaba sobre la mesa de trabajo en allowed herself the luxury of dreaming about poetry and of creating without time constraints, as one does during childhood, when urgency does not exist. She would lose herself in neverending collective games that gradually became more and more relevant in her creative endeavours.

Her quest for a more festive humanism caused her to take an interest in the games and activities that enrich people's lives, whether that involved fun events, exhibitions or objects. So it was that her imaginary universe became full of toys, merry-go-rounds, carts, puppets, trains, small creatures such as insects or larger beings like Polochón and the Great Mechanical Cow. By analysing them, we see that they fulfilled a dual purpose: ludic and pedagogical. ${ }^{14}$ This seemingly contradictory duality linking intellectual education to play is also shown in her architecture. Many of these toys were part of her collective architecture and were responsible for triggering activity and enhancing the collective potential of the spaces they were in. As Mara Sánchez rightfully said, "toys and games were the precursors of the complex Bobardian work". 15

The spaces Bo Bardi designed were intended to house happiness, which for the architect meant an encounter with freedom. Her work provided the setting for great celebrations for children and adults, a place in which to set aside inhibitions, fears and prejudice and give in to mystery, surprise and the pleasure of play. That play was free yet regulated, with the ability to take on a relevant social and cultural dimension stemming from a concept of collectivity that proved essential in her work.

This open, flexible attitude shown in her work, which succeeded in accommodating the unforeseeable essence and joy of everyday life, was also found in the way she projected. Lina did not project at a desk in the distance of a 
la distancia del estudio, sino in situ, a pie de obra, tomando decisiones oportunas, atenta a los imprevistos, resolviendo los problemas conforme van surgiendo, en la cercanía de los operarios y trabajadores, atendiendo las recomendaciones de estos y de sus colaboradores.

- Museo de Arte de São Paulo

En la avenida Paulista, en la actualidad colmatada de rascacielos, Lina proyectó el Museo de Arte de São Paulo (19581968). Este fue concebido como un volumen horizontal suspendido que contrastaba con la verticalidad de los edificios próximos y que configuraba un vacío, un espacio colectivo, que se cedía a la ciudad como lugar de encuentro e intercambio (Fig. 01). studio, but rather in situ, right at the site where the construction would stand, allowing her to make very appropriate decisions bearing in mind unexpected situations, solving problems as they came, in close contact with the workers and builders, heeding their advice and that of her collaborators.

\section{- Museum of Art of São Paulo}

Lina projected the Museum of Art of São Paulo on Avenida Paulista (19581968), which is currently flanked by skyscrapers. It was conceived as a suspended horizontal volume to strike a contrast with the verticality of the buildings around it, creating an empty, collective space that was delivered to the city as a place for gatherings and exchanges (Fig. 01).
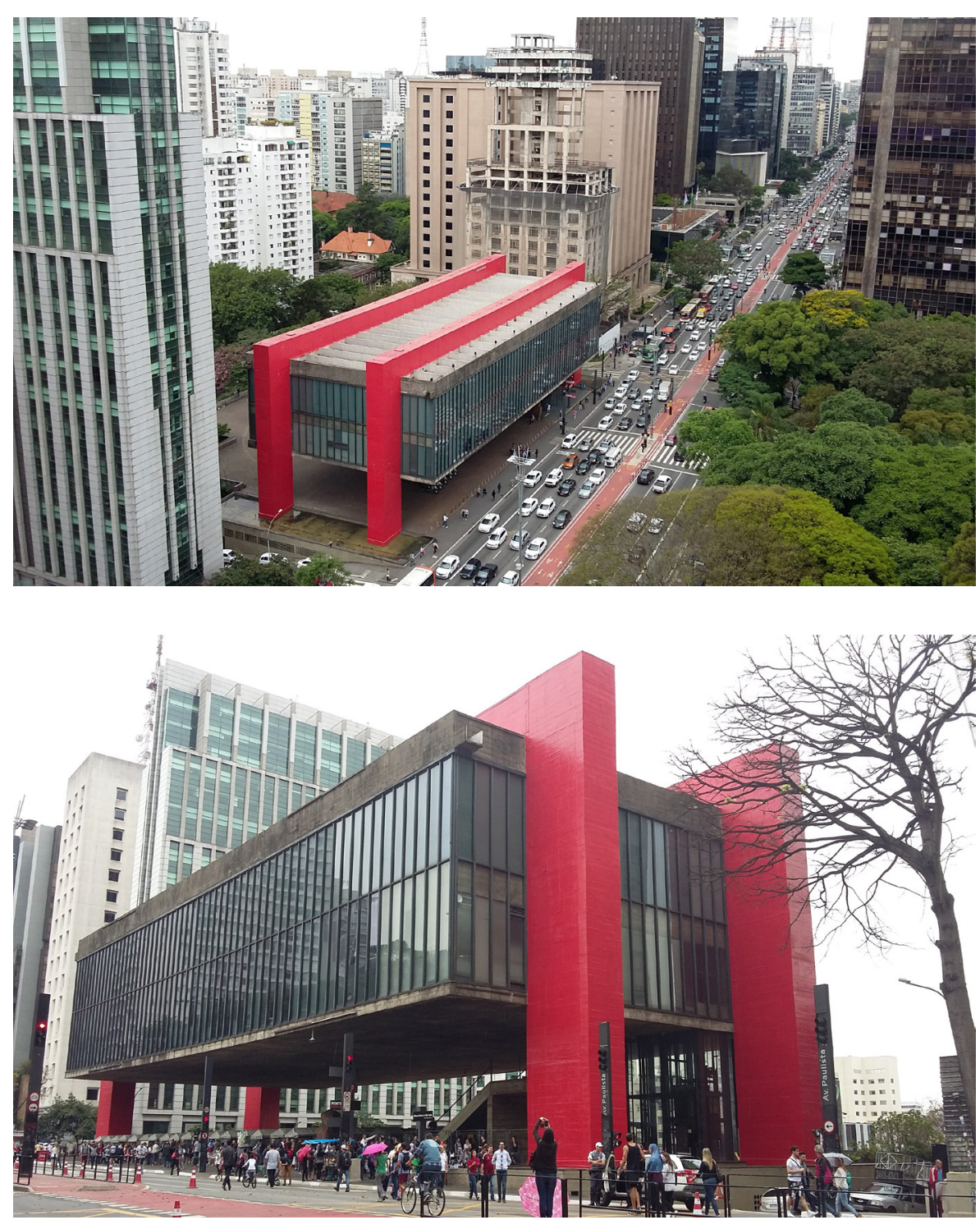

01. Lina Bo Bardi, Museo de Arte de São Paulo (MASP), São Paulo (Brasil), 1958/68; vista aérea.

02. Lina Bo Bardi, Museo de Arte de São Paulo (MASP), São Paulo (Brasil), 1958/68; fotografia desde la Avenida Paulista.

01. Lina Bo Bardi, Museum of Art of São Paulo (MASP), São Paulo (Brazil), 1958/68; view from above.

02. Lina Bo Bardi, Museum of Art of São Paulo (MASP), São Paulo (Brazil), 1958/68; photograph taken from Avenida Paulista. 
Lina concibió el MASP como un "museo más allá de los límites". ${ }^{16}$ Siempre tuvo el deseo de que el arte llegara a la calle e impregnase de alegría la vida de los ciudadanos. ${ }^{17} \mathrm{~A}$ través de la plaza generada en el nivel inferior, bajo el edificio expositivo, Lina invitaba a los ciudadanos a formar parte del museo, fusionando de manera magistral arte y vida cotidiana, lo público y lo privado, lo popular y lo culto ${ }^{18}$ (Fig. 02).

En su proyecto museográfico, bajó la pintura del pedestal y la expuso sobre unas láminas de vidrio templado que contaban con un soporte de hormigón y que rememoraban la posición del cuadro en el caballete del artista (Figs. 03 y 04). La disposición de los cuadros llevaba al visitante a observarlas como lo haría el artista y a recorrerlas mezclándose entre ellas, invitándole a sentirse partícipe de esta acción creativa.

Para Lina, el arte debía ser el reflejo de una nueva sociedad y surgir desde la alegría, la inocencia y la valentía. En sus acuarelas y dibujos, próximos a aquellos que elaboró durante su adolescencia en Italia, Lina propuso una apropiación lúdica del espacio urbano de la plaza, que se prolongaba en una explanada en forma de Belvedere sobre la ciudad, a partir de su ocupación temporal como zona de juego infantil. Lina planificó bajo el museo un espacio de encuentro, de diversión a través de exposiciones, conciertos, mercados y parques infantiles, un espacio abierto a cualquier tipo de manifestación popular y un lugar para la fiesta, la fantasía y el ocio. Toboganes, carruseles, molinillos, globos terráqueos, laberintos, bancos corridos y hasta un circo, que acabó instalándose en 1972 en el vano del MASP con motivo del cincuenta aniversario de la Semana de Arte Moderna de Sao Paulo, elementos todos ellos presentes de forma incondicional en el imaginario de Lina, colmataban sus propuestas para este espacio donde niños y adultos jugaban y se relacionaban libremente, dando rienda suelta a sus impulsos.

En sus dibujos, que iban desde el diseño de su arquitectura hasta el mobiliario pasando por las salas de exposiciones y escenografías, Lina trató de registrar
Lina conceived the MASP to be "a museum beyond limits". ${ }^{16}$ She always wished for art to invade the streets and impregnate the lives of citizens. ${ }^{17}$ The square on the ground floor beneath the exhibition building was where Bo Bardi invited citizens to become part of the museum, masterfully blending art with everyday life, public with private, popularity with education ${ }^{18}$ (Fig. 02).

In her museum project, Lina took paintings down from the pedestal and exhibited them on panes of tempered glass with a concrete stand, reminding visitors of a work of art on an easel (Fig. 03 and 04). The paintings were arranged so that viewers could see them the way the artist would and wander along amidst them, inviting the audience to feel like part of the creative action.

For Lina, art should be the reflection of a new society and should arise from joy, innocence and bravery. Her watercolour paintings and drawings, which were similar to those produced as a teenager in Italy, called for this urban square to be given a playful purpose, extending into a belvederelike esplanade over the city, temporarily becoming a children's play area. Lina planned for this area beneath the museum to be a place for gathering, for fun exhibitions, concerts, markets and playgrounds, a venue opened to all kinds of popular demonstrations and a place for celebration, fantasy and leisure. Slides, merry-go-rounds, toy windmills, globes, mazes, long benches and even a circus were set up inside the MASP's square, the latter in 1972 to celebrate the 50th anniversary of the São Paulo Modern Art Week. All of these elements were unconditionally present in Lina's imaginary, filling her ideas for this space where children and adults could play and interact freely, letting their whims and fancies run free.

Her drawings covered everything from the architecture to the furniture, including exhibition rooms and scenography. Through these drawings, 


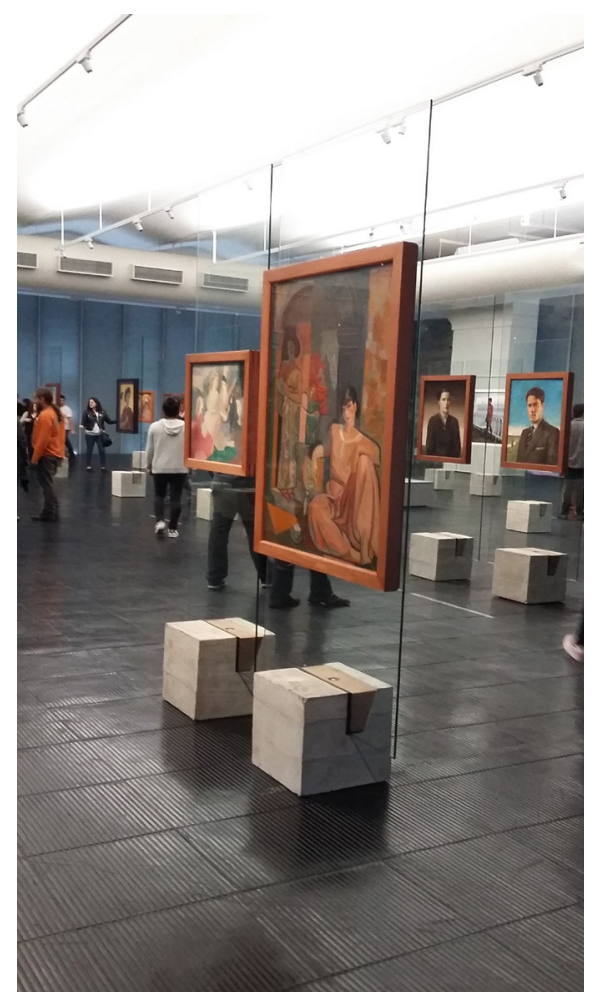

la infinidad de opciones posibles para este espacio que en la actualidad se configura como un lugar abierto a una multiplicidad de usos colectivos: plaza, espacio para exposiciones de arte, manifestaciones, concentraciones políticas, conciertos de música, zona de juego, feria de antigüedades, actividades creativas, etc. que reflejan un espíritu libre y festivo. Pero este espacio también fue ideado como un lugar donde albergar juguetes como la Gran Vaca Mecánica, 1988, un objeto expositivo diseñado por Lina con el objetivo de dispensar las entradas del MASP y exponer objetos populares fuera del edificio del museo buscando una convivencia juguetona con sus visitantes.

\section{- SESC Pompéia}

En su propuesta para el SESC Pompéia (1977-1986), Lina recuperó por completo las instalaciones de una antigua fábrica de sombreros a partir de unas obras mínimas pero exactas de acondicionamiento para el desarrollo de actividades deportivas y culturales (Figs. 05 y 06). Cuando Lina visitó las instalaciones de esta antigua fábrica de forma previa a la realización del proyecto, se encontró con que la gente del barrio ya había colonizado de forma espontánea y hecho uso de

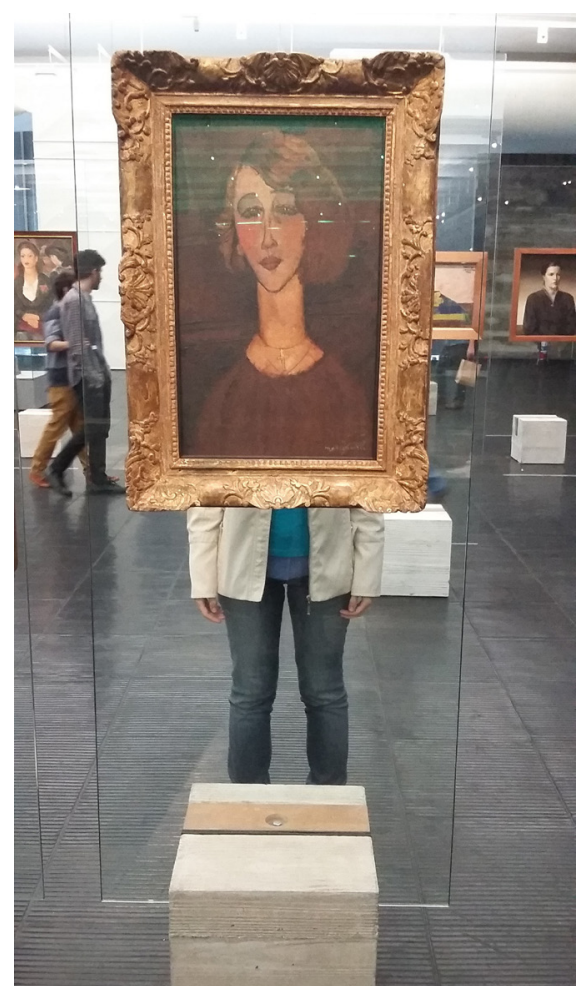

03. Lina Bo Bardi, Museo de Arte de São Paulo (MASP), São Paulo (Brasil), 1958/68; vista interior de la sala de exposiciones principal.

04. Lina Bo Bardi, Museo de Arte de São Paulo (MASP), São Paulo (Brasil), 1958/68; vista interior de la sala de exposiciones principal, detalle del caballete diseñado por Lina.

03. Lina Bo Bardi, Museum of Art of São Paulo (MASP), São Paulo (Brazil), 1958/68; view from inside the main exhibition hall.

04.Lina Bo Bardi, Museum of Art of São Paulo (MASP), São Paulo (Brazil), 1958/68; view from inside the main exhibition hall, details of the easel designed by Bo Bardi.
Bo Bardi sought to record the endless options this space could house, which is currently open to a multitude of collective uses: square, art exhibition area, a place for demonstrations and political gatherings, music concerts, games, antique shows, creative activities and many more that reflect the free, festive spirit she had intended to achieve. This space was also conceived to house toys like the Great Mechanical Cow in 1988, an exhibition item designed by Lina to dispense tickets for the MASP and display folk objects outside the museum building in an effort to build a creative bond with visitors.

\section{- SESC Pompéia}

Bo Bardi's idea for the SESC Pompéia (1977-1986) allowed her to completely restore the old hat factory with some very minimal but precise refurbishment work to host sports events and cultural activities (Fig. 05 and 06). When Lina visited the old factory before starting the project, she found that the local residents had already spontaneously colonised and begun to use the facilities for everyday activities linked to leisure and play. 
05. Lina Bo Bardi, SESC Pompéia, São Paulo (Brasil), 1977/86; vista exterior.

06. Lina Bo Bardi, SESC Pompéia, São Paulo (Brasil), 1977/86; vista exterior.

05. Lina Bo Bardi, SESC Pompéia, São Paulo (Brazil), 1977/86; view from outside.

06. Lina Bo Bardi, SESC Pompéia, São Paulo (Brazil), 1977/86; view from outside. estas instalaciones para el desarrollo de actividades de la vida cotidiana ligadas al ocio y al juego. Las escenas de lo que allí contempló quedaron grabadas en su memoria y fueron determinantes en la definición posterior del proyecto y la elaboración del programa. ${ }^{19}$

La prioridad de Lina fue mantener y amplificar toda aquella vitalidad que allí se encontró. Transformó este espacio fabril en un lugar mágico, creado a partir del diseño de ambientes lúdicos donde la distinción entre el juego y la vida cotidiana no existía. Lina preservó la imagen de la fábrica, pero subvirtió su sentido. ${ }^{20}$ No en vano el SESC fue apodado como "ciudadela de la libertad".

El SESC proyectado por Lina daba forma a una arquitectura que incorporaba la imprevisibilidad de la vida cotidiana, en lugar de tratar de contenerla y reglarla. El resultado fue un espacio colectivo capaz de dar respuesta a cada una de las actividades de la vida cotidiana en los días festivos, un lugar donde poder leer, tomar el sol, pasear, hacer deporte, visitar una exposición, celebrar una fiesta o asistir al teatro, entre otras muchas actividades (Figs. 07-11). Todas estas acciones fueron representadas por Lina a través de una extensa colección de bocetos que evocaban los sencillos trazos de sus dibujos infantiles. La reducción de líneas, las texturas imprecisas y los intensos contrastes de color expresaban la emoción y el afecto por el desorden y la alegría de la vida que este proyecto trataba de capturar.
The scenes she witnessed there were etched in her memory and would prove decisive in the project's subsequent definition and the elaboration of the programme. ${ }^{19}$

Lina's priority was to maintain and amplify all the vitality she had encountered. She converted this factory setting into a magical place by designing ludic atmospheres where the distinction between play and everyday life was nonexistent. Lina preserved the factory's appearance but reinvented its purpose. ${ }^{20}$ It is no coincidence that the SESC was labelled the "citadel of liberty".

The SESC that Bo Bardi envisioned embodied an architecture that embraced the unpredictability of everyday life instead of trying to contain and govern it. The result was a collective space with the capacity to cater for all of the everyday activities of a festivity, a place to read, sunbathe, do exercise, see an exhibition, hold a party or go to the theatre, for example (Fig. 07, 08, 09, 10 and 11). Lina depicted each and every one of those activities in a long series of sketches that evoked the simple strokes of her childhood drawings. Soft lines, imprecise textures and striking colour contrasts portrayed her emotions and her liking for disorder and joy in life, which is what the project intended to capture.
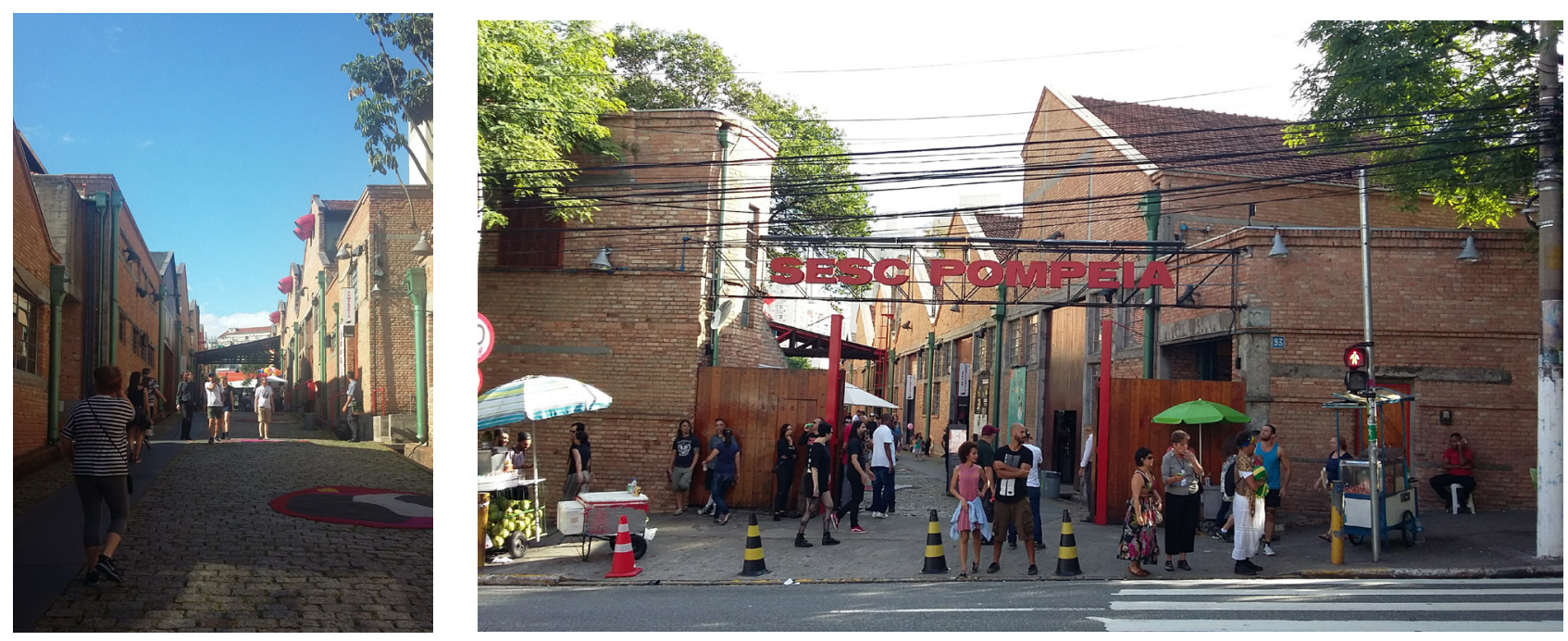

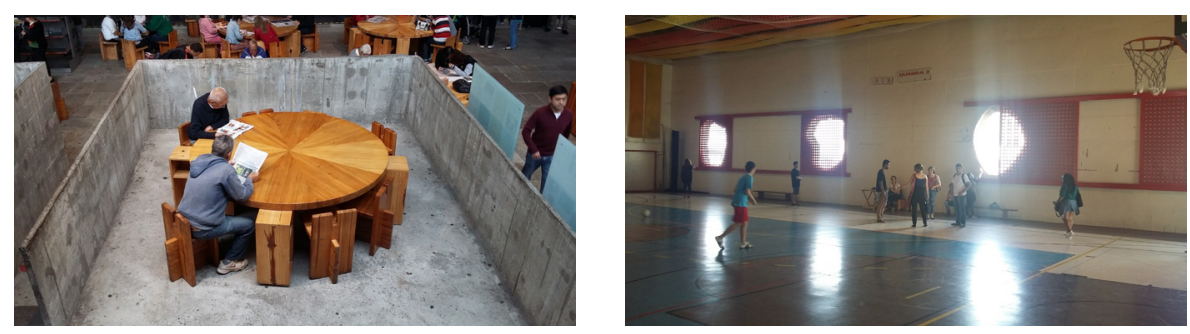

07-11. Lina Bo Bardi, SESC Pompéia, São Paulo (Brasil), 1977/86; vistas interiores.

07-11. Lina Bo Bardi, SESC Pompéia, São Paulo (Brazil), 1977/86; view from inside.
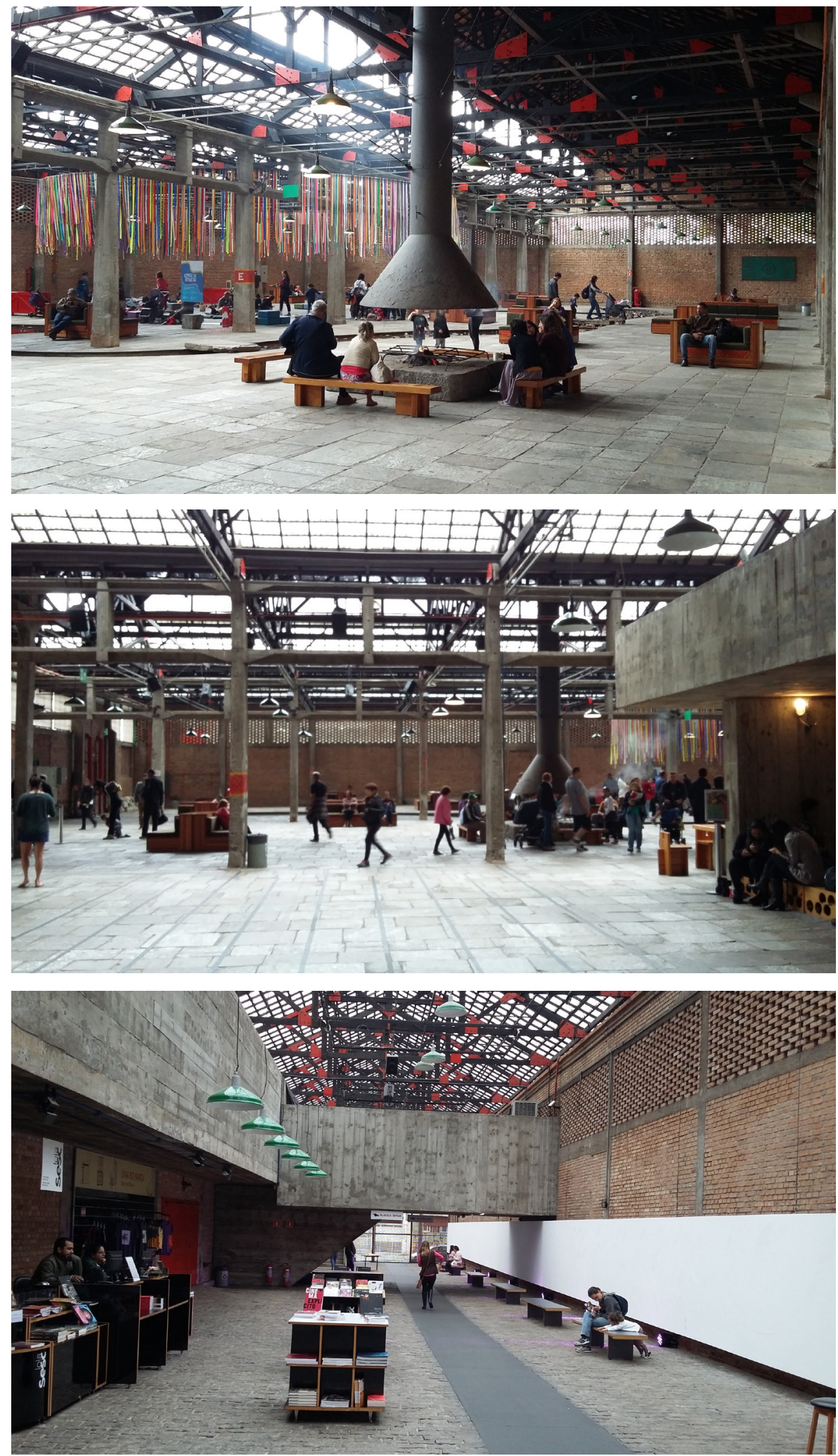


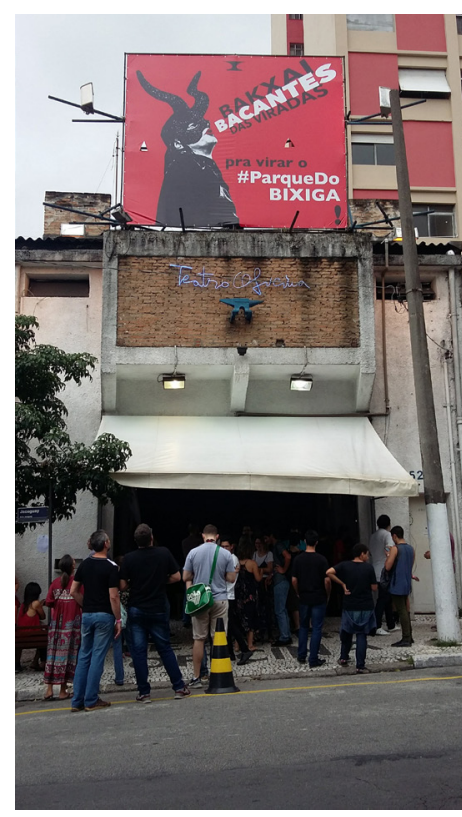

12. Lina Bo Bardi, Teatro Oficina, São Paulo (Brasil), 1980/91; vista

exterior.

12 Lina Bo Bardi, Teatro Oficina, São Paulo (Brazil), 1980/91; view from outside.
Lina trató de materializar programas que alimentasen la vida colectiva y el ocio como parte de la cultura cotidiana. Asimismo, diseñó un juguete móvil que denominó Pequeńo Tren de Carritos, 1985, formado por cuatro carritos de colores realizados con material reciclado y dos locomotoras a ambos extremos. Este tenía como objetivo dar soporte a las distintas actividades programadas, así como insinuar con sus paradas la existencia de estas.

Así pues, el SESC fue concebido como un lugar aglutinador de manifestaciones artísticas, abierto a los condicionamientos intersubjetivos de los usuarios que dejaban de ser meros espectadores para convertirse en co-creadores o creadores con proyección social. ${ }^{21} \mathrm{~A}$ estos dedicó Lina este proyecto $^{22}$, pero prestando especial atención a un público infantil. Así pues, diseñó diversas exposiciones como Pinocchio (1983), Entreato para crianças (1985) o Mil brinquedos para a criança brasileira (1982) que trataban de convertir el acto expositivo en una gran fiesta para nińos y adultos. En esta última, aquellos juguetes infantiles del nordeste que Lina coleccionó obsesivamente a lo largo de su vida constituyeron una parte fundamental de la exposición.

\section{- Teatro Oficina}

En el Teatro Oficina (1980-1991), Lina interviene restaurando un antiguo teatro. El proyecto fue concebido a partir de una mínima intervención arquitectónica que le llevó a proyectar el teatro como una calle-escenario, abierta al exterior, al sol, la lluvia, los ruidos,... y que se prolongaba hacia el espacio urbano para alcanzar la calle ${ }^{23}$ (Figs. 12-15).

En este proyecto, lo preexistente y lo nuevo, así como lo construido y el espacio público convivían del mismo modo que lo hacían los actores y espectadores $^{24}$ (Fig. 16). Lina buscó expandir la fantasía, la libertad y la alegría del mundo del teatro hacia el espacio urbano, sacando el teatro a la calle e involucrando al espectador, haciéndole partícipe de esta expresión teatral y provocando que los actores recibieran estos imprevistos y se apropiasen de ellos.
Lina sought to materialise programmes that would nourish collective life and leisure as part of everyday culture. She also designed a small mobile toy called Little Train of Carts in 1985, which comprised four colourful carts made of recycled materials with two train engines at the front and back. Its function was to support the various activities and to represent their existence with every stop of the train.

In short, the SESC was conceived as an agglutinating place for artistic expression, open to the inter-subversive conditioning of its users who instead of being mere onlookers would become co-creators or in fact creators with social significance. ${ }^{21}$ Bo Bardi dedicated this project to users ${ }^{22}$, but with a special focus on the youngest audience. She designed a series of exhibitions such as Pinocchio (1983), Entreato para crianças (1985) and Mil brinquedos para a criança brasileira (1982), all of which sought to turn the act of the exhibition into a celebration for children and adults. In the last of these three productions, the children's toys from the Northeast that Lina had collected obsessively over the years became a key part of the exhibition.

\section{- Teatro Oficina}

Lina's work on the Teatro Oficina (19801991) involved restoring an old theatre. The project was conceived to entail only the slightest architectural reform, leading her to envisage the theatre as a sort of street stage exposed to the outdoors, the sun, the rain, the noise... opening out into its urban surroundings to reach the $\operatorname{street}^{23}$ (Figs. 12-15).

In this project, all that existed previously and all that was new, all that had been built and all that was public space coexisted just as actors and spectators do $^{24}$ (Fig. 16). Bo Bardi intended to spread the fantasy, freedom and joy of the world of theatre into urban space, bringing theatre to the street and engaging the audience, involving them in this theatrical expression and exposing the actors to unpredictable surprises which they would embrace and include in their work. 

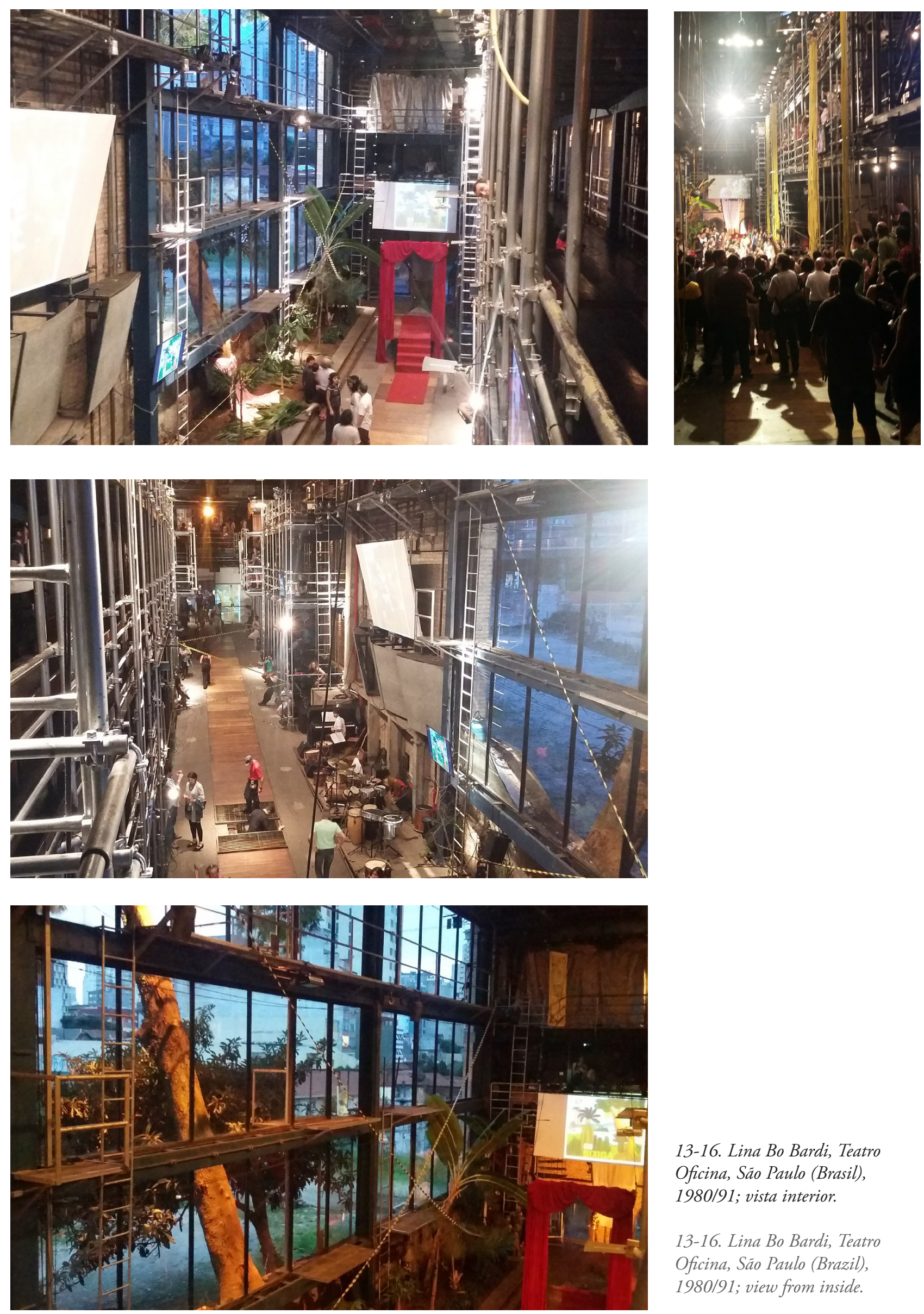

13-16. Lina Bo Bardi, Teatro Oficina, São Paulo (Brasil), 1980/91; vista interior.

13-16. Lina Bo Bardi, Teatro Oficina, São Paulo (Brazil), 1980/91; view from inside. 
Lina recibió además el encargo de realizar la escenografía y el vestuario para la representación de la obra teatral $U B U$. Folias, Pataphysicas e Musicaes del autor Alfred Jarry. Para esta obra diseñó dos objetos escenográficos: Dodecaedro y Polochón (ambos de 1985) proyectados para dar la bienvenida a los espectadores. Dodecadro era el resultado de la transformación geométrica de la flor de Mandacarú y tenía su origen en un juguete popular del nordeste brasileño. Polochón, el cerdo de dos cabezas, era un animal imaginario de exótica morfología. Ambos objetos teatrales fueron diseñados para desencadenar mecanismos creativos buscando la implicación y participación de los espectadores, lo que les convertía en juguetes colectivos.

\section{Conclusiones}

Lina fue una mujer de gran temperamento, una arquitecta inusual, con una peculiar sensibilidad humana evidenciada en todas y cada una de sus obras. Su trabajo creativo, inimitable, contempla creaciones imaginativas e intransigentes ${ }^{25}$ que reflejan un espíritu libre y festivo. Una lectura superficial de su obra nos llevaría a leerla como una arquitectura feliz, fruto de una intuición libre y fantástica. Sin embargo, la observación atenta y minuciosa de su proceso creativo a través de sus bocetos y estudios previos, nos lleva a desvelar que detrás de su desorbitante fantasía e imaginación se encuentra la complejidad y profundidad de un trabajo serio, riguroso, coherente, autocrítico y comprometido con la sociedad. ${ }^{26}$

Su pensamiento osciló dentro y fuera de la cultura moderna, tratando de encontrar el equilibrio entre la razón y la realidad de la vida. Situó al hombre en el centro de sus prioridades. Su arquitectura se hizo abierta, porosa para incorporar la alegría e imprevisibilidad de la vida cotidiana. A través de su obra trató de materializar programas que alimentaran la vida colectiva y abrazasen la forma de vivir de la gente.

Detrás de la fuerza y el atractivo de sus proyectos construidos nos encontramos con el esfuerzo de tratar de conciliar principios estéticos y humanísticos. En
Lina was also entrusted to take care of the stage design and costumes for the theatre representation of UBU. Folias, Pataphysicas e Musicaes written by Alfred Jarry. She designed two props for the play: Dodecaedro and Polochón (both in 1985), which were intended to welcome the audience. Dodecaedro was the outcome of geometrically transforming a flower known as Mandacaru, inspired by a folk toy from the Northeast of Brazil. Polochón, the two-headed pig, was an imaginary animal with an exotic morphology. These two theatre items were designed to trigger creative mechanisms by seeking to involve and engage viewers, making them collective toys.

\section{Conclusions}

Lina was a spirited woman, an unusual architect with a peculiar human sensitivity shown in each and every one of her works. Her creative, inimitable work contemplated imaginative and intransigent creations ${ }^{25}$ that reflect a free and festive spirit. If we were to read her work superficially, we would see a happy architecture enriched by free intuition and fantasy. However, a more careful, painstaking analysis of her creative process based on her sketches and preliminary studies reveals that behind her wild fantasy and imagination lay the complexity and depth of very serious, thorough, coherent, self-critical and socially committed work. ${ }^{26}$

Her thinking swayed in and out of modern culture in an effort to find the balance between reason and reality. She placed people at the heart of her priorities. Her architecture became open and porous to absorb the joy and unpredictability of everyday life. She geared her work towards materialising programmes that would nourish collective life and embrace people's way of living it.

Behind the strength and appearance of the projects she built, we see how hard she worked to reconcile aesthetic and human principles. In her will 
su deseo de ofrecer una versión festiva e inédita del ser humano, introdujo el juego, entendido como un elemento social, en su obra. Su actitud entusiasta, apasionada y sensible le llevó a afirmar que "si volviera a nacer, solo coleccionaría fantasías, emociones y alegrías”. ${ }^{27}$

Lina proyectó desde el rigor y la coherencia, pero en el desarrollo de su actividad creativa se sumergió con la misma actitud lúdica con la que un niño juega a inventar mundos y ciudades imaginarias. La fuerza de sus proyectos construidos convivía con pequeńos muebles infantiles, juguetes, exposiciones, etc. que no solo participaban de la acción colectiva propuesta por la arquitectura, sino que enriquecían la cualidad colectiva y lúdica de estos espacios. Su arquitectura se desarrolló "como juego y dentro del juego". ${ }^{28}$ Los objetos creados por Lina, las exposiciones que diseñó, así como los proyectos arquitectónicos que construyó participan de las características del juego, lo que les convierte a todos ellos en juguetes.

Lina se mantuvo a lo largo de toda su trayectoria profesional tal y como Joaquim Guedes la describió: "Exigente, rigurosa, aplicada en todo y, por esto, radical; pero elegante, generosa y lúdica”. ${ }^{29}$

\section{Notas}

1. Bo Bardi, Lina citado en Fabio Malavoglia, Entrevista con Lina Bo Bardi. Texto no publicado (São Paulo: Instituto Lina Bo e Pietro Maria Bardi, 1986).

2. Lina se refirió con las siguientes palabras a Brasil: "Un país inimaginable, donde todo era posible, viviendo en una atmósfera humana y cordial”. Bo Bardi, Lina citado en Silvia Odebrecht, "Autenticidad y carácter en la arquitectura de Lina Bo Bardi (19141992)," Arquitectura y Urbanismo, Vol. XXVII, no. 2-3 (2006): 24

3. Mara Sánchez, Lina Bo Bardi. Objetos y acciones colectivas (Buenos Aires: Nobuko, 2015), 13.

4. Lina Bo Bardi (Achillina di Enrico Bo) siempre fue conocida en Brasil con el nombre de Lina. Este el nombre que sus colaboradores y la gente con la que to show a festive and unknown side of humankind, she introduced play, conceived as a social element, into her work. Her enthusiastic, passionate and sensitive attitude led her to say "If I were born again, I would only collect fantasies, emotions and joys". ${ }^{27}$

Bo Bardi's projects stemmed from thoroughness and coherence, but while developing her creative activity she would be overtaken by the same playful attitude as a child pretending to build a city and worlds of make-believe. The power of her constructed projects coexisted with small pieces of children's furniture, toys, exhibitions, etc. These elements not only involved the creative action proposed by architecture, but also enriched the collective and playful quality of her spaces. Her architecture developed "as play and within play". ${ }^{28}$ The objects Lina created, the exhibitions she designed, and the architectural projects she built involved the characteristics of play, turning them all into toys.

Lina remained exactly as Joaquim Guedes had described her throughout her career: "Demanding, thorough, engaged and consequently radical; yet elegant, generous and playful". ${ }^{29}$

\section{Notes}

1. Bo Bardi, Lina cited in Fabio Malavoglia, Entrevista con Lina Bo Bardi. Unpublished text (São Paulo: Instituto Lina Bo e Pietro Maria Bardi, 1986).

2. Lina used the following words to describe Brazil: "An unimaginable country where everything was possible, draped in a humane and friendly atmosphere". Bo Bardi, Lina cited in Silvia Odebrecht, "Autenticidad y carácter en la arquitectura de Lina Bo Bardi (19141992)," Arquitectura y Urbanismo, Vol. XXVII, no. 2-3 (2006): 24.

3. Mara Sánchez, Lina Bo Bardi. Objetos y acciones colectivas (Buenos Aires: Nobuko, 2015), 13.

4. Lina Bo Bardi (Achillina di Enrico Bo) was always known by the name Lina in Brazil. This was the name given to her by collaborators and the people 
se relacionó utilizaban al referirse a ella. Asimismo, es el que aparece en muchos de los textos y bibliografía utilizada en el desarrollo de este artículo. En adelante, se utilizará el nombre de Lina para referirse a la arquitecta con el fin de ser consecuente a los aspectos de forma y estilo adoptados.

5. Zeuler R. Lima, "Comprometida con la vida," AV Monografias. Lina Bo Bardi, 1914-1992, no. 180 (2015): 6-13.

6. Elena Pérez Guembe, "Pieles sensibles. La iglesia del Espíritu Santo: una lectura en homenaje al buen hacer de Lina Bo Bardi y a la buena reflexión de Iñaki Ábalos,” Dearq, no. 20 (2017):48-59.

7. Con estas palabras lo expresó Lina: "Lo que fue importante en mi vida fue el viaje al noreste y el trabajo que desarrollé en el Polígono de las Secas. Entonces vi la libertad. La no importancia de la belleza, de la proporción, de esas cosas, pero de otro sentido más profundo, que he aprendido con la arquitectura de los fuertes (...) en todo el nordeste de Brasil. (...) Debo a Brasil esta libertad de la mesa del sujetapapeles, de las reglas y de los escenarios". Bo Bardi, Lina citado en Malavoglia, Entrevista con Lina Bo Bardi, 4.

Como ella misma confesó a sus colaboradores: "Todo lo que busqué en Italia al término de la guerra, lo encontré aquí. Aquí están las condiciones ideales para construir un País moderno". Bo Bardi, Lina citado en Marcelo Ferraz, "Salsinha de poucos pratos," $A$ tarde cultural, 23 de outubro de 1993, Suplemento Cultural, 1993, 3.

8. Johan Huizinga, Homo Ludens (Madrid: Alianza editorial, 2012).

9. Sánchez, Lina Bo Bardi, 303

10. Lina lo expresa con las siguientes palabras: "Eu nunca quis ser jovem. O que eu queria era ter história. Com vinte e cinco anos queria escrever minhas memórias, mas não tinha matéria”. Lina Bo Bardi citado en Marcelo Ferraz (org.), Lina Bo Bardi São Paulo: Instituto Lina Bo e Pietro Maria Bardi, 1993), 9.

11. Ana Carolina de Souza Bierrenbach, "Entre adultos e crianças: consideraçóes sobre o processo criativo de Lina Bo Bardi," Pós. Revista do Programa de Pós-Graduação em Arquitetura e Urbanismo da FAUUSP, v. 15, no. 24 (2008): 44-61.

12. "Ela desenhava sempre com lápis e caneta, adorava caneta BIC. (...) Desenhava muito bem de observação. Desenhava 'planta' como ninguém, e desenhava umas flores, uma coisa impressionante, tinha a mão solta, um desprendimento de quem sabe desenhar, ou seja, nấo tinha censura que em geral todo adulto tem. (...) É lógico, ela tinha um kit de desenho, uma aquarela dessas japonesas de criança, sabe? (...) Ela adorava aquilo. Aquela aquarela com cores leves. Também desenhava com lápis, e para apagar o lápis, usava massa de pão. Engraçado, você sabe o que é? É borracha, para limpar, desengordurar she interacted with. This is also the name written in many of the texts and bibliographic works referenced to produce this paper. The names Lina and Bo Bardi will be used from here onwards to refer to the architect for the sake of consistency in terms of form and style.

5. Zeuler R. Lima, "Comprometida con la vida," AVMonografias. Lina Bo Bardi, 1914-1992, no. 180 (2015): 6-13.

6. Elena Pérez Guembe, "Pieles sensibles. La iglesia del Espíritu Santo: una lectura en homenaje al buen hacer de Lina Bo Bardi y a la buena reflexión de Iñaki Ábalos," Dearq, no. 20 (2017):48-59.

7. Lina used these words to express it: "What was really important in my life was my journey to the Northeast and the work I did at the Las Secas estate. That was when I saw freedom. The importance of beauty, proportion, that sort of thing, but in a more profound sense, one that I have learned through the work of strong architects (...) all across the Northeast of Brazil. (...) I owe to Brazil that freedom from a desk with a paper clip, rules and stages”. Bo Bardi, Lina cited in Fabio Malavoglia, Entrevista con Lina Bo Bardi, 4.

As she herself admitted to her collaborators: "All that I had been looking for in Italy at the end of the war, I found it here. Here are the ideal conditions to build a modern country”. Bo Bardi, Lina cited in Marcelo Ferraz, "Salsinha de poucos pratos," A tarde cultural, 23 de outubro de 1993, Suplemento Cultural, 1993, 3.

8. Johan Huizinga, Homo Ludens (Madrid: Alianza editorial, 2012).

9. Sánchez, Lina Bo Bardi, 303.

10. Lina used these words to express this idea: "I never wanted to be young. What I wanted was to have a history. At the age twenty-five I wished to write my memoirs, but I had no content". Lina Bo Bardi cited in Marcelo Ferraz (org.), Lina Bo Bardi (São Paulo: Instituto Lina Bo e Pietro Maria Bardi, 1993), 9.

11. Ana Carolina de Souza Bierrenbach, "Entre adultos e crianças: consideraçốes sobre o processo criativo de Lina Bo Bardi," Pós. Revista do Programa de Pós-Graduação em Arquitetura e Urbanismo da FAUUSP, v. 15, no. 24 (2008): 44-61.

12. "She always drew using a pencil and a pen. She adored BIC pens. (...) She was a very good observational drawer. She drew 'plants' like no-one else, and she drew flowers amazingly. She had skill, the ease of someone who knows how to draw, as in she did not feel the censorship that adults tend to have. (...) It makes sense. She had a drawing kit, a child's Japanese watercolours, you know? (...) She loved it. She loved those watercolours with light tones. She would also draw with a pencil. Then, to soften the pencil she would use bread rubber. It's fun. Do you know what it is? It is rubber for cleaning and 
o desenho. Desenhava com o comportamento de uma criança". Marcelo Ferraz citado en Achylles Costa Neto, "A liberdade desenhada por Lina Bo Bardi" (diss., Universidade Federal do Rio Grande do Sul, 2003).

13. Itten, Johannes citado en Magdalena Droste, Bauhaus 1919-1933 (Berlín: Taschen, 2006), 38

14. Sánchez, Lina Bo Bardi, 300.

15. Sánchez, Lina Bo Bardi, 167

16. De este modo lo expresó Pietro María Bardi, fundador del museo.

17. Sánchez, Lina Bo Bardi.

18. Olivia de Oliveira, Subtle substances, the architecture of Lina Bo Bardi (Barcelona: Romano Guerra Editora Ltda. Gus $\neg$ tavo Gili, 2006), 12.

19. Con las siguientes palabras Lina Bo Bardi describió esta escena: "La segunda vez que estuve allí, un sábado, el ambiente era distinto: ya no era aquella elegante y solitaria estructura diseñada por François Hennebique, sino un público alegre de niños, madres, padres y ancianos que pasaban de un pabellón a otro. Había niños que corrían, jóvenes que jugaban futbol bajo la lluvia que caía de los techos fisurados, que reían cuando pateaban el balón entre los charcos. Las madres preparaban asados y sándwiches en la entrada de la calle Clélia; donde un pequeńo teatro guiñol daba funciones rodeado de nińos. Y pensé: todo esto debe continuar así, con tanta alegría. Volví muchas veces, los sábados y los domingos, hasta fijar en mi mente con claridad aquellas alegres escenas populares". Silvana Rubino y Marina Grinover (org.), Lina Bo Bardi por escrito: textos escogidos 1943-1991 (México: Alias, 2014), 191.

20. "Aquí el trabajo se convierte en aliado del placer, y no su opuesto. Elimina del trabajo ese carácter desagradable, represivo, violento y penoso, para relacionarlo con la sensibilidad, la libertad, la imaginación y la lívido. El logotipo diseñado para el nuevo conjunto, con una chimenea que expulsa flores en vez de humo, lo expresa con claridad". Olivia de Oliveira, "Hacia Lina Bo Bardi," Revista 2G, Lina Bo Bardi, no. 23/24 (2003): 5.

21. Sánchez, Lina Bo Bardi.

22. Con las siguientes palabras los expresó: "Yo nunca olvido el surrealimo del pueblo brasileńo, sus inventos, su placer por estar todos juntos, por bailar, cantar. Así pues, dediqué mi trabajo en el Pompéia a los jóvenes, a los niños, a la tercera edad: todos juntos". Lina Bo Bardi, "Na Pompéia. O Bloco Esportivo", Casa Vogue, Nov.-Dic. (1986):134.

23. En su diseño, Lina tuvo presente las palabras de Le Corbusier que recordó en este pasaje: "Teatro que sale a las plazas, a las calles, que invade la ciudad, sillas y muebles que salen de las casas, y gente, hombres, mujeres, niños, todo un pueblo que inspiró, en 1963, a Le Corbusier, cuando degreasing the drawing. She drew with the behaviour of a child". Marcelo Ferraz cited in Achylles Costa Neto, "A liberdade desenhada por Lina Bo Bardi" (diss., Universidade Federal do Rio Grande do Sul, 2003).

13. Itten, Johannes cited in Magdalena Droste, Bauhaus 1919-1933 (Berlín: Taschen, 2006), 38.

14. Sánchez, Lina Bo Bardi, 300.

15. Sánchez, Lina Bo Bardi, 167.

16. This was how Pietro María Bardi, the Museum’s founder, explained it.

17. Sánchez, Lina Bo Bardi.

18. Olivia de Oliveira, Subtle substances, the architecture of Lina Bo Bardi (Barcelona: Romano Guerra Editora Ltda. Gus-tavo Gili, 2006), 12.

19. These were the words used by Lina Bo Bardi to describe the scene: "The second time I went there, on a Saturday, the atmosphere had changed: it was no longer that lonely, elegant structure designed by François Hennebique; instead, it was a lively audience full of children, mothers, fathers and elderly people going from one hall to the next. There were children running around, youngsters playing football in the rain that dripped through the cracks in the ceiling, laughing as they kicked the ball around the puddles. Their mothers were making a roast and sandwiches at the entrance on Calle Clélia, where a small puppet theatre was putting on shows surrounded by children. And I thought to myself that everything should stay as it was, full of joy. I went back many times, on Saturdays and Sundays, until I managed to fix the image of those joyful folk scenes clearly in my mind". Silvana Rubino and Marina Grinover (org.), Lina Bo Bardi por escrito: textos escogidos 1943-1991 (México: Alias, 2014), 191.

20. "Here, work becomes the ally of pleasure instead of an opponent. It takes away that unpleasant, repressive, violent and sad element from work and links it to sensitivity, freedom, imagination and lust. The logo designed for the new complex, with a chimney puffing out flowers instead of smoke, expresses it clearly". Olivia de Oliveira, "Hacia Lina Bo Bardi," Revista 2G, Lina Bo Bardi, no. 23/24 (2003): 5 .

21. Sánchez, Lina Bo Bardi.

22. She expressed it in the following words: "I will never forget the surrealism of the Brazilian people, their inventions, their pleasure at being together, dancing, singing. So it was that I dedicated my work in Pompéia to youngsters, children and the aged: all together". Lina Bo Bardi, "Na Pompéia. O Bloco Esportivo”, Casa Vogue, Nov.-Dic. (1986):134.

23. In her design, Lina took into account the words of Le Corbusier, which she recalled in this fragment: "Theatre that goes out into the squares, the streets, invading the city; chairs and furniture coming out of homes, and people, men, women and children, an entire people, who inspired Le Corbusier in 1963 when he 
visitaba Brasil, en una famosa carta al ministro Gustavo Capanema: -Señor Ministro, no mande construir teatros con escenarios y butacas, deje las Plazas, las Calles, el Verde, libres, mande solamente construir 'tablados' de madera, abiertos al Pueblo, y el Pueblo Brasileño los ocupará, 'improvisando', con su elegancia natural y su inteligencia”. Lina Bo Bardi, "Pequena comunicação sobre restauro na arquitetura na Bahia”, Archivo Instituto Lina Bo e P. M. Bardi, Évora, septiembre de 1989.

24. Héctor Navarro Martínez y Manuel Blanco Lage, "Interiores exteriorizados, tres casos de estudio en la arquitectura brasileńa: Mendes da Rocha, Lina Bo Bardi e Isay Weinfeld," Arquitecturas del Sur, vol. 35, no. 51 (2017): 6-19.

25. Odebrecht, "Autenticidad y carácter,"

26. Mara Sánchez Llorens, "La gran vaca mecánica," Circo, no. 161 (2010): 1-6.

27. Lina Bo Bardi citado en Bo Bardi, Lina citado en Malavoglia, Entrevista con Lina Bo Bardi, 1986 28. Sánchez, Lina Bo Bardi, 300.

29. Joaquim Guedes citado en Antonella Gallo (org.), Lina Bo Bardi architetto (Venezia: Marsilio, 2004), 15.

\section{Procedencia de las ilustraciones}

Figs.01-16. Fuente propia.

\section{Sobre la autora}

María Isabel Alba Dorado es Doctora Arquitecta y Profesora Ayudante Doctor del Área de Proyectos Arquitectónicos de la Escuela Técnica Superior de Arquitectura de la Universidad de Málaga (España).

maribelalba@uma.es visited Brazil, in a famous letter he wrote to the minister Gustavo Capanema: -Mister Minister, do not order the construction of theaters with stages and seats, but leave open the squares, the streets, and the gardens of the city. Have them build wooden platforms and benches and the Brazilian people will occupy them, 'improvising' as always with their natural elegance and intelligence". Lina Bo Bardi, "Pequena comunicação sobre restauro na arquitetura na Bahia”, Archivo Instituto Lina Bo e P. M. Bardi, Évora, September 1989.

24. Héctor Navarro Martínez and Manuel Blanco Lage, "Interiores exteriorizados, tres casos de estudio en la arquitectura brasileña: Mendes da Rocha, Lina Bo Bardi e Isay Weinfeld," Arquitecturas del Sur, vol. 35, no. 51 (2017): 6-19.

25. Odebrecht, "Autenticidad y carácter,".

26. Mara Sánchez Llorens, "La gran vaca mecánica," Circo, no. 161 (2010): 1-6.

27. Lina Bo Bardi cited in Fabio Malavoglia, Entrevista con Lina Bo Bardi, 1986.

28. Sánchez, Lina Bo Bardi, 300.

29. Joaquim Guedes cited in Antonella Gallo (org.), Lina Bo Bardi architetto (Venezia: Marsilio, 2004), 15.

\section{Source of illustrations}

Fig. 01-16. Author's photographs.

\section{About the author}

María Isabel Alba Dorado is a PhD Architect and an Assistant Professor of the Area of Architectural Design at the School of Architecture of the University of Málaga (Spain).

maribelalba@uma.es 